\title{
FEATURES OF EUTHANASY IN EASTERN ASIA COUNTRIES
}

\author{
Buletsa S. B.
}

"Killing both pain and patient may be good
morals, but is far from certain it is good law."
Lord Edmund Davies

\section{INTRODUCTION}

Human life is a special gift, and in various decisions to continue or discontinue treatment, or to maintain life artificially, special care must be taken. If the patient has no chance of recovery and medical treatment is limited to maintaining his or her condition, it may be a matter of assisting in accelerating death by removing the life support system from the deceased patient at the request of relatives or the patient himself. It should be noted that compassionate death is a euphemism ${ }^{1}$ for euthanasia.

The issue of euthanasia is being raised around the world, including in Asia. More attention is given to patient autonomy to address life and death. The urgency is that there is a need to consider protecting the right of a mentally competent patient to refuse medical treatment or to receive assistance, if he or she needs it, in ending his or her unbearable suffering by introducing a deadly substance to the patient. The legal status of the competent patient as well as the patient in clinical death should also be specified. Issues relating to the treatment of terminally ill people are currently being dealt with on very specific terms, and there is a degree of uncertainty in the minds of the general public and medical staff about the legal position on this issue. Doctors and families want to act in the best interests of the patient but are unsure of the scope and content of their care responsibilities. In addition, doctors are afraid of being sued, prosecuted and convicted if they shut down life support systems or prescribe drugs that inadvertently or otherwise shorten a patient's life, even if they only act as the patient wishes.

\section{Legal regulation of euthanasia in Japan}

The current Japanese legal system is based on a civil law system modeled on European legal systems of the XIX century, especially the legal codes of Germany and France. The Meiji Constitution was an organic law of the

\footnotetext{
${ }^{1}$ Dictionary of the Ukrainian language: in 11 volumes. Volume 2. 1971. Page. 453. URL: http://sum.in.ua/s/evfemizm (accessed: September 26, 2019). Euphemism - a word or expression that is replaced in the language by a rude, obscene, with an unpleasant emotional color word.
} 
Japanese Empire, which operated from 1890 to 1945. After World War II, great legal reform took place, and the 1947 Constitution was drawn up under the occupation of the Allies, with considerable American influence. The current Japanese legal system is a hybrid of continental and American law. Both the concepts of civil law and the later effects of common law influence traditional Japanese values.

Yes, Shinto and Buddhism are two major religions of Japan. Shintoism is as old as Japanese culture, and Buddhism was imported from the mainland in the 6th century. Since then, both religions are relatively harmonious and even complement each other to some extent. Some scholars highlight the religious features of euthanasia, including:

1) Buddhism and Christianity are united in their opposition to euthanasia.

2) Buddhist and Christian opposition to euthanasia comes from the common rejection of the consequentialist reasoning in favor of an approach that respects a person's life as a fundamental rather than an instrumental good.

3) both Buddhism and Christianity teach that life is not absolute value and must be preserved at all costs and emphasize the transience of life.

4) the consensus of Buddhism and Christianity on euthanasia challenges pessimism about the possibility of moral consensus and support for the belief that the world's religions have a common core of values. Given that there is no predicted general consensus on euthanasia, the optimism expressed in these statements remains valid ${ }^{2}$. In most Asian countries, euthanasia is forbidden because of religious motives, which makes it impossible to legislate, but that does not mean that it is not applicable. The definitions and classifications of euthanasia in Japan are somewhat different from those adopted in the West. The Japanese term for euthanasia, "arak-shi", literally means peaceful ("arak") death ("shi"), much attention was paid to its role in the mitigation of "terminal illness", but less attention was paid to the patient, his own decision than in Western countries. The term "euthanasia" in Japan does not mean mercy, "murder", but is defined as a peaceful death and therefore covers a range of actions that are not considered euthanasia in Western countries.

Most Japanese researchers (Kai, 1995; Kanda, 1996; Kanazawa, 1961; Machino, 1993, 1995; Naito, 1984) have identified euthanasia as an act to ease the pain of patients and allow them to die peacefully in the final stages of a terminal illness in a situation of serious physical suffering without the prospect of recovery. Ending unbearable physical pain is the reason that entitles them to die. In Japan, monitoring the suffering of people around the

\footnotetext{
${ }^{2}$ Roy W Perrett. Buddhism, euthanasia and the sanctity of life. Journal of Medical Ethics. 1996. № 22. P. 311-312. URL: http://buddhism.lib.ntu.edu.tw/FULLTEXT/JR-ADM/perrett.htm (accessed: 26.09.2019 p.)
} 
patient is also important, meaning not only the will or request of the patient. This provision was reflected in the decision of the Nagoya High Court, where the criteria were laid down in $1972^{3}$. Unfortunately, Western countries do not pay attention to the pain of loved ones, which in my opinion is incorrect, since suffering, the experiences of loved ones are important factors for the patient to decide on the possibility of euthanasia.

In Japan, euthanasia is conditionally classified into four types: 1) active euthanasia; 2) indirect euthanasia; 3) passive or negative euthanasia; 4) pure euthanasia. Active euthanasia is the deliberate acceleration, without therapeutic purpose, of the end of life of a patient who is in the final stages of a terminal illness or endures serious physical suffering without the prospect of recovery.

This definition of "euthanasia" is usually found in Europe. Indirect euthanasia is a treatment to relieve the symptoms of agony, but with side effects that reduce the life of a terminally ill patient, it is generally not considered problematic in the West. "Passive euthanasia" is defined as a refusal to treat terminally ill patients, and although it does not fall within the definition of euthanasia in the West, nevertheless, this type of euthanasia is a matter of moral concern. "Passive euthanasia" is defined as a refusal to treat terminally ill patients, and although it does not fall within the definition of euthanasia in the West, nevertheless, this type of euthanasia is a matter of moral concern. Pure euthanasia is a treatment to alleviate the symptoms of severe pain in a terminally ill patient, with no significant consequences of reducing life but facilitating peaceful death (an approach called palliative care in the West). Although it is classified as euthanasia in Japan, the "pure euthanasia" procedure is not against the law, since the patient's life is not interrupted by another person's intervention. Active, indirect, passive euthanasia is legally controversial in Japan as it is related to the termination of the patient's life. However, the goal of pure euthanasia is to eliminate intolerable physical pain, which is the primary goal of all types of euthanasia in Japan ${ }^{4}$.

It should be emphasized that Japan is a country of tradition of civil law. Courts have to make decisions in accordance with laws and regulations, but they are not related to the decisions of other courts. Consequently, although the above decisions provided for euthanasia criteria, this does not mean that other courts are required to comply with these requirements. Doctors,

\footnotetext{
${ }^{3}$ Miki Hayashi, Toshinori Kitamura. Euthanasia trials in Japan: Implications for legal and medical practice. International Journal of Law and Psychiatry. № 25. 2002. P. 560. URL: https://www.sciencedirect.com/journal/international-journal-of-law-andpsychiatry/vol/25/issue/6 (accessed: 26.09.2019 p.)

${ }^{4}$ Miki Hayashi, Toshinori Kitamura. Euthanasia trials in Japan: Implications for legal and medical practice. International Journal of Law and Psychiatry. № 25. 2002. P. 561-570. URL: https://www.sciencedirect.com/journal/international-journal-of-law-and-psychiatry/vol/ 25/issue/6 (accessed: 26.09.2019 p.)
} 
patients, and patients' relatives cannot fully predict the results of their behavior in accordance with these decisions. In summary, Japan does not allow doctors to assist in suicide and is cautious about making surrogate decisions. If patients do not make informed decisions before losing consciousness, doctors are required to treat them if family members cannot clearly identify patients' wishes. However, since there is no law governing informed consent, and patients rarely sign out to refuse treatment, it is not known how to handle cases involving unconscious patients who do not have a Living Will ${ }^{5}$.

The Japanese government itself has not issued any formal laws on the legalization of euthanasia, and the Japanese Supreme Court has never resolved the issue. Instead, to date, euthanasia policy in Japan has been resolved by two local court cases, one in Nagoya in 1962 and the other following an incident at Tokai University in 1995. The first case took place in Nagoya in 1962 and concerned "passive euthanasia" (that is, allowing a patient to die by disabling life support), the other - and in the latter case, "active euthanasia" (for example, by injection).

The court decisions in these cases set the legal framework and set of conditions in which both passive and active euthanasia can be legal. However, in both cases, doctors were found guilty of violating these conditions when they deprived their patients of their lives. Moreover, since the findings of these courts are not yet substantiated at the national level, these precedents are not binding. However, there is currently an indicative legal framework for euthanasia in $\operatorname{Japan}^{6}$.

Thus, as we can see, Japan is very slow in considering euthanasia legislation. However, this does not mean that in Japan, reducing the life of terminally ill patients is rare. Rather, this means that such a state of affairs is justified by the unwillingness to discuss euthanasia openly. The frequency of euthanasia is unknown, as no direct applications have been reported.

There is still no law in Japan that recognizes passive or active euthanasia. However, several euthanasia-related court cases have been conducted in Japan over the past decade (although the Supreme Court's decision is still pending). Since the Kochi case in 1990, euthanasia in Japan has been discussed more openly in Japan. The social foundation of this new openness has been the development of an aging society that has emerged in recent years. In this regard, the public is more interested in the problems of long life and terminal treatment and care.

${ }^{5}$ Chih-hsiung Chen. Legislating the Right-To-Die With Dignity in a Confucian Society. Taiwan's Patient Right to Autonomy. Act 42 HastingsInt'l \& Comp. L. Rev. 2019. 485. URL: https://repository.uchastings.edu/hastings_international_comparative_law_review/vol42/ iss2/4 (accessed: 26.09.2019 p.)

${ }^{6}$ Euthanasia. Basic knowledge of modern terminology. Jiyukisma. 2007. P. 951, 953. (安楽 死 ". 現代 用語 の 基礎 知識. 自由 国民 社. 2007). 
Let us return to the decision made after the incident at the University of Tokai. Thus, on March 28, 1995, the Chief Justice of the Yokohama District Court in the mercy killing case at Tokai University issued a judgment, part of which contained a legal text allowing active euthanasia. Active euthanasia requires the following four conditions: 1) patient death is inevitable and unchanged; 2) the patient suffers from unbearable physical pain; 3) the doctor has already done everything possible to eliminate physical pain, that is, palliative care and there are no other alternatives, and finally, 4) the patient's wish to die is open, clear and understandable ${ }^{7}$.

Even in the abstract, these four conditions are problematic. For example, the rapid improvement of painkillers made intolerable physical pain very rare, as it was possible to introduce the patient into a medicated sleep (sedation). If we focus on the willingness of doctors to strictly adhere to these conditions for active euthanasia, the situation is more troubling. One of the main factors is paternalism, because the doctor, as the father who cares for his child, sympathizes with the patient, helps him, takes responsibility for his decision making about his treatment.

The use of a small amount of euthanasia does not mean that the latter is exceptional in Japan, on the contrary, it is carried out discreetly. The details of these cases indicate the following:

1) palliative care for terminal patients is short in time in terms of pain control and psychological care;

2) there is a lack of informed consent and respect for the patient's autonomous decision-making;

3) lack of a clear statement of the patient's wishes;

4) euthanasia is performed by family members suffering from the burden of care;

5) a strong paternalistic tradition impedes the growth of patient autonomy in Japanese medical care ${ }^{8}$.

Japanese scientists believe, first, that euthanasia should be accessible only to adults who can understand that it signifies a permanent end to their lives, as confirmed in the Nagoya and Yokohama Court decisions.

Second, the Yokohama District Court found that all possible palliative care should be provided, that is, palliative care should be provided to patients and include both pain control and psychiatric care. When palliative care cannot resolve intolerable physical pain, then euthanasia can be considered.

\footnotetext{
${ }^{7}$ Kenzo Hamano. Should Euthanasia be Legalized in Japan? The Importance of the Attitude Towards Life. URL: https://www.eubios.info/ABC4/abc4110.htm (accessed: 26.09.2019 p.)

${ }^{8}$ Miki Hayashi, Toshinori Kitamura. Euthanasia trials in Japan: Implications for legal and medical practice. International Journal of Law and Psychiatry. 2002. № 25. P. 557-571. URL: https://www.sciencedirect.com/journal/international-journal-of-law-and-psychiatry/vol/ 25/issue/6 (accessed: 26.09.2019 p.)
} 
Third, inevitable death was included in the court's decisions as an incurable disease (Nagoya High Court) and as an inevitable death (Yokohama District Court). Courts have stated that they believe that a necessary criterion should be the inevitable death without the prospect of relief from the suffering of the terminally ill.

However, if death must be inevitable, then euthanasia ceases to be an accessible option in all cases of incredible suffering. It is believed that relief from unjustified pain of death as a basic principle of euthanasia means that euthanasia should also be accessible to those who suffer from severe, refractory and long-term physical pain when death is an inevitable result, even if it is not.

Fourth, the Nagoya High Court criteria required euthanasia to be performed by a physician using an ethically acceptable method. Lawyer Kai $(1995)^{9}$ argued that the Yokohama District Court found it quite clear that euthanasia would be performed by a doctor. Others believe that the person who physically administers the euthanasia facility does not necessarily need to be a doctor while the latter is present.

Fifth, by the criteria of the Nagoya court, the pain observed by the patient's loved ones is the primary criterion. However, since pain is a subjective experience, we can say that the main criterion is the request of the patient, determined on the basis of pain.

Finally, none of these criteria requires a second opinion to confirm that the conditions for euthanasia are satisfactory, and that it is best to suggest that a family doctor or general practitioner who has probably known the patient for some time should suggest euthanasia ${ }^{10}$.

Thus, in Japan for the application of passive euthanasia must meet three conditions:

1. The patient must suffer from an incurable disease and be in the final stages of a disease that he / she is unlikely to recover from;

2. The patient must give his expressed consent to discontinuation of treatment, and this consent must be obtained and maintained until the latter's death. If the patient is unable to give clear consent, their consent can be determined using a previous written document, such as a living will or family testimony;

${ }^{9}$ Kai K. (1995, March 28). Chiryoukouityuushi oyobi anrakushi no kyoyouyouken-Toukaidaigaku byouin "anrakushi” - jiken hanketsu (Heisei 7.3.28, Yokohama Chisai hanketsu) (Permissible euthanasia - Tokai University "euthanasia”' case (Judgement of Yokohama District Court)). Hougakukyoushitsu, 178. P. 37-45; Kai I., Ohi, G., Yano, E., Kobayashi, Y., Miyama, T., Niino, N., \& Naka, K. (1993). Communication between patients and physicians about terminal care: a survey in Japan. Social Science and Medicine. 1993. Vol. 36. P. 1151-1158.

${ }^{10}$ Miki Hayashi, Toshinori Kitamura. Euthanasia trials in Japan: Implications for legal and medical practice. International Journal of Law and Psychiatry. 2002. № 25. P. 557-571. URL: https://www.sciencedirect.com/journal/international-journal-of-law-and-psychiatry/vol/25/ issue/6 (accessed: 26.09.2019 p.) 
3. The patient may be subjected to passive euthanasia by discontinuation of medication, chemotherapy, dialysis, artificial respiration, blood transfusion, IV drip and the like ${ }^{11}$.

Four conditions are required for active euthanasia:

1. The patient should suffer from intolerable physical pain;

2. Death must be inevitable and approaching;

3. The patient must give consent (as opposed to passive euthanasia, where there is not enough living will and consent of the family);

4. The doctor has exhausted all other anesthetic measures or they have proved ineffective.

The resulting issues, in addition to the problem faced by many other families in the country, have led to the creation of "bioethics teams". These groups will be available to families of terminally ill patients to help them, together with their doctors, come to a decision based on personal case studies $^{12}$.

\section{Some aspects of euthanasia in South Korea}

The legal system of South Korea is a system of civil law, which has its basis in the Constitution of the Republic of Korea.

Korea itself is a country where all major world religions, such as Christianity, Buddhism, Confucianism, and Islam, coexist peacefully with shamanism. Thus, according to 2015 statistics, 44\% of the Korean population professes one or another religion. First of all, the question of euthanasia legalization is influenced by religion. The question of legalization is primarily influenced by religion.

Like Japan in South Korea, "family" is a core value and emphasizes the concepts of harmony and filial piety. Just like in Japan, jurisprudence has been deeply influenced by euthanasia in South Korea. In particular, the debate on euthanasia began as early as December 4, 1997, when the doctor was sent to prison for a long term, for voluntary termination of life support for a patient with brain death. This incident is well known in Korea as the "Boramae Hospital Incident", (보라매 병원 사건). In this case, a patient who underwent craniotomy were admitted to the ICU of the hospital through subarachnoid bleeding. The patient's wife went to the hospital with a request to discharge patients, due to the impossibility of payment for treatment. The doctor dismissed a patient who died after 36 hours. And his wife was accused of murder. The Supreme court decision in 2004 in this case led to

11 “Euthanasia”. Basic knowledge of modern terminology. Jiyukisma. 2007. P. 951, 953. (“安楽死”. 現代 用語の基礎 知識. 自由 国民 社. 2007).

${ }^{12}$ McDougall Jennifer Fecio. Gorman Martha. Euthanasia: A Reference Handbook. Santa Barbara: ABC-CLIO. 2008. 270p. ${ }^{12}$ "Евтаназія". Основні знання сучасної термінології. Jiyukisma. 2007. C. 951, 953. (“安楽死”. 現代用語の基礎知識. 自由国民社. 2007.) 
the indictment of two doctors for help and incitement to murder. The court believed that this case is governed by the law of the voluntary dismissal, not euthanasia or worthy of death. At the time, the South Korean public was little debate about euthanasia or death with dignity, terminal dismissal from the hospital was not yet legal. After the proceedings, many doctors believed that the discharge terminal patients and discontinuation of treatment of patients where this is possible, even if there is a reasonable justification for relatives for the refusal of it is illegal ${ }^{13}$.

Another incident that sparked further debate was the imprisonment of a father who had disconnected a respirator for his son with brain death ${ }^{14}$. The reports indicate that South Korea had previously legalized passive euthanasia but maintained the illegality of active suicide as of December 2015, a bill called "Death with Dignity ${ }^{15}$."

In the future, the legal situation changed in the case of grandmother Kim in 2008. Grandmother Kim was a 76-year-old patient with a permanent vegetative condition who had no previous instructions. The family asked the doctor to withdraw treatment. The request was rejected by the hospital and the family filed a lawsuit.

The district court agreed that, in the absence of the patient's prior instructions, the patient's wishes could be withdrawn because she had rejected a tracheotomy for her dying husband. The patient also said when she realized that "I want to leave this life without becoming a burden to others". As a result, the district court ruled that life-sustaining treatment could be canceled. Although the hospital appealed to the Court of Appeal, the appeal was dismissed ${ }^{16}$. In 2009, the Supreme Court of Seoul (Korea) ordered doctors to remove Eluana Englaro, an elderly woman (76 years old), from a ventilator who was diagnosed with a persistent vegetative brain death during the year previous wishes ${ }^{17}$. This has led to increased awareness of the rights of terminally ill patients and a public debate about the futile maintenance of

${ }^{13}$ Chih-hsiung Chen. Legislating the Right-To-Die With Dignity in a Confucian Society. Taiwan's Patient Right to Autonomy. Act 42 HastingsInt'l \& Comp. L. Rev. 2019. 485. URL: https://repository.uchastings.edu/hastings_international_comparative_law_review/vol42/iss2/4 (accessed: 6.09.2019).

${ }^{14}$ Tanya Thomas. Euthanasia Legal for the Terminally Ill In S. Korea Now. Med India. Retrieved 15 July 2010. URL: https://www.medindia.net/news/euthanasia-legal-for-theterminally-ill-in-skorea-now-71327-1.htm (accessed: 26.09.2019).

15 Alex Schadenberg. Korea has not legalized euthanasia or assisted suicide. Life site. Retrieved 14 December 2015. URL: https://www.lifesitenews.com/pulse/korean-has-notlegalized-euthanasia-or-assisted-suicide (accessed: 26.09.2019).

${ }^{16}$ Chih-hsiung Chen. Legislating the Right-To-Die With Dignity in a Confucian Society Taiwan's Patient Right to Autonomy. Act 42. HastingsInt'l \& Comp. L. Rev. 485 (2019). URL: https://repository.uchastings.edu/hastings_international_comparative_law_review/vol42/iss2/4 (accessed: 21.05.2019 p.)

${ }^{17}$ South Korea Authorizes Country's First Mercy Killing. URL: https://www.fastcase.com/ blog/south-korea-authorizes-coutrys-first-mercy-killing/ (last accessed: 26.09.2019). 
life in unjustified treatment. In February 2016, the Court ruled that patients could make life-sustaining treatment decisions, and in February 2018, doctors would be able to withhold or refuse life-support treatments such as chemotherapy, lung ventilation, cardiopulmonary resuscitation and hemodialysis from dying patients. This will have a serious impact on decision-making to end life in Korea ${ }^{18}$.

Regarding legislative support, there are two laws in South Korea governing patients' decisions to discontinue treatment. The Cancer Law guarantees that cancer patients are eligible for palliative care. However, such care is limited to patients with cancer. Doctors are not required to explain terminal conditions to patients and their families, and there is no provision for informed consent. Another law, passed in 2016 by the Law on Hospice Care for Lifespan, allows terminally ill people aged 19 and over to claim lifesupportive care.

This act was put into effect in February 2018. Life-sustaining treatment is legally defined under the following conditions: cardiopulmonary resuscitation (CPR), hemodialysis, cancer treatments, and artificial respirators.

This act does not cover palliative care, artificial nutrition and hydration, or oxygen masks (breathing without reliance on technique). Authorization of a patient's wishes requires the signature of a patient, two professional doctors and a witness. This law also stipulates that, in the event that patients are unable to express a desire or decision, they may receive hospice care. In addition, two or more family members may agree to provide hospice services based on the patient's intended wishes and personality ${ }^{19}$.

There has been a public debate in Korea on passive euthanasia and refusal to maintain viability, taking into account current medical and legal practice. Discontinuation of treatment to maintain viability with the primary intention of ending the life of an unconscious patient (eg, in a vegetative state), and the patient could survive with such treatment is considered passive euthanasia and is prohibited in the country. However, the termination

${ }^{18}$ Young Ho Yun, Kyoung-Nam Kim, in-Ah Sim, Shin Hye Yoo, Miso Kim, Young Ae Kim, Beo Deul Kang, Hyun-Jeong Shim, Eun-Kee Song, Jung Hun Kang, Jung Hye Kwon, Jung Lim Lee, Eun Mi Nam, Chi Hoon Maeng, Eun Joo Kang, Young Rok Do, Yoon Seok Choi, and Kyung Hae Jung. Attitudes of Cancer Patients, Family Caregivers, Physicians, and the General Population toward Modes of Death. Comparison of attitudes towards five end-of-life care interventions (active pain control, withdrawal of futile life-sustaining treatment, passive euthanasia, active euthanasia and physician-assisted suicide): a multicentred cross-sectional survey of Korean patients with cancer, their family caregivers, physicians and the general Korean population. URL: https://www.ncbi.nlm.nih.gov/pmc/articles/PMC6144336/ (last accessed: 26.09.2019).

${ }^{19}$ Chih-hsiung Chen. Legislating the Right-To-Die With Dignity in a Confucian Society. Taiwan's Patient Right to Autonomy. Act 42 HastingsInt'l \& Comp. L. Rev. 2019. 485 (2019). URL: https://repository.uchastings.edu/hastings_international_comparative_law_review/vol42/ iss2/4 (last accessed: 26.09.2019). 
of viability, although it may be limited by passive euthanasia, permits natural death, when death is imminent even after medical treatment, it is not a lifethreatening action.

However, despite the ban on euthanasia, most Koreans support the failure to maintain viability in vain, offering the possibility that passive euthanasia will be widely discussed after the Supreme Court's decision in February 2018 for Korean over-age society.

Korean doctors are more negative about active end-of-life (Active Physician-assisted death (PAD) euthanasia and Physician-assisted suicide (PAS) suicide.) A suicide doctor is a doctor who provides a means of death where the patient, rather than the doctor, will eventually administer the aircraft. Although, I note that euthanasia usually means that the doctor will act directly, such as giving a lethal injection to terminate a patient's life.

For example, Elizabeth Kubler-Ross identified five stages of the dying process: denial, anger, bargaining, depression, and acceptance. After twenty years of experience in the study of this type of terminally ill patient, she claims that physician-assisted suicide is wrong. There are many studies suggesting that terminally ill patients may change their mind about the possibility of physician-assisted suicide ${ }^{20}$. Therefore, the function of the latter will be reduced to helping die.

PAD and PAS are still illegal in Korea (as well as in China and Japan). Although the Supreme Court of Canada legalized the PAD in 2015. There has been a public debate in Korea about passive euthanasia. Discontinuation of treatment with the primary intention of terminating the life of an unconscious patient (eg, a vegetative patient) who could survive with such treatment is considered to be passive euthanasia and is prohibited. However, stopping useless living support when death is imminent even after medical treatment is not a life-saving act.

The share of positive attitudes towards euthanasia or physician-assisted suicide in Korea is relatively low compared to the Netherlands, USA and Canada, where $60-90 \%$ of patients support these procedures. Koreans, as a rule, support only a conservative choice of patient care, which is not surprising ${ }^{21}$, because of the cultural values of the country.

${ }^{20}$ Gupta B.D. Euthanasia: Personal Viewpoint. Jpafmat. 2004. № 4. P. 18. URL: http://medind.nic.in/jbc/t04/i1/jbct04i1p17.pdf (accessed: 26.09.2019 p.)

${ }^{21}$ Young Ho Yun, Kyoung-Nam Kim, in-Ah Sim, Shin Hye Yoo, Miso Kim, Young Ae Kim, Beo Deul Kang, Hyun-Jeong Shim, Eun-Kee Song, Jung Hun Kang, Jung Hye Kwon, Jung Lim Lee, Eun Mi Nam, Chi Hoon Maeng, Eun Joo Kang, Young Rok Do, Yoon Seok Choi, and Kyung Hae Jung. Attitudes of Cancer Patients, Family Caregivers, Physicians, and the General Population toward Modes of Death. Comparison of attitudes towards five end-of-life care interventions (active pain control, withdrawal of futile life-sustaining treatment, passive euthanasia, active euthanasia and physician-assisted suicide): a multicentred cross-sectional survey of Korean patients with cancer, their family caregivers, physicians and the general Korean population. URL: https://www.ncbi.nlm.nih.gov/pmc/articles/PMC6144336/ (accessed: 26.09.2019). 
The National Assembly and the Ministry of Health and Welfare of Korea have voted in favor of active and passive euthanasia in the Well-Dying Bill $^{22}, 22$ which came into force in February 2018.

Patients eligible for active or passive euthanasia in South Korea are terminally ill patients with no chance of recovery. Patients who have a favorable response to any medication or are not in rapid deterioration of their health leading to inevitable death are not euthanized.

They must have confirmation from a registered physician and physician to die with dignity, and patients with coma must have the approval of both caregivers $^{23}$.

Japanese scientists are also of the opinion that euthanasia should not be legislated, but rather a recommendation system that is more flexible and does not impose sanctions ${ }^{24}$.

On April 13, 2001, Associated Press reported that "mercy killings" were illegal in South Korea. But the Korean Medical Association (70,000 doctors) has developed a new draft code of ethics that will give doctors greater leeway in determining the fate of patients from unbearable pain without the hope of living. Without a clear legal definition of mercy killing in South Korea, doctors were restless when they treated patients who they believed were terminal and unbearable and had several days to live. In a widely publicized case in 1998, a Seoul doctor was sentenced to $21 / 2$ years in prison for allowing an terminally ill patient to go home and die without further treatment at the request of his wife ${ }^{25}$. Korea's Ethics Code of Ethics was adopted in 2001 (6 sections, 78 articles), revised in 2006 (1 section, 8 articles), and in 2017, revised (10 articles) ${ }^{26}$, permits physicians to discontinue treatment for terminally ill patients or at their own discretion will be asked to do so in writing by the family of patients and also allow doctors

\footnotetext{
${ }^{22}$ New law enables South Koreans to 'die well". The Straits Times. 2016-01-28. Retrieved 29 January 2016. https://www.straitstimes.com/asia/east-asia/new-law-enables-south-koreansto-die-well (accessed: 26.09.2019).

${ }^{23}$ Choi Won-woo. 조선일보. Korea to Temporarily Allow Terminally Ill Patients to Choose Death with Dignity. Retrieved 23 October 2017. URL: http://english.chosun.com/site/ data/html_dir/2017/10/23/2017102301468.html (accessed: 26.09.2019).

${ }^{24}$ Katsunori Kai. Euthanasia and Death with Dignity in Japanese Law. Waseda Bulletin of Compartive Law. 2010. Vol. 27.. URL: https://www.waseda.jp/folaw/icl/assets/uploads/ 2014/05/A02859211-00-000270001.pdf (accessed: 26.09.2019).

${ }^{25}$ Ole Doering. Euthanasia, and the Meaning of Death and Dying: A Confucian Inspiration for Today's Medical Ethics. 2001. P. 56. URL: https://pdfs.semanticscholar.org/1f3f/ a32d070818eb636a0be4f261eb69a24a314a.pdf (accessed: 26.09.2019).

${ }^{26}$ Ock-Joo Kim, Yoon Hyung Park, Byung Gee Hyun. Development of the codes and guidelines of medical ethics in Korea. J Korean Med Assoc. 2017. № 60 (1). P. 8-17. URL: https://www.jkma.org/search.php?where=aview\&id=10.5124/jkma.2017.60.1.8\&code=0119JKMA\& vmode=FULL (accessed: 26.09.2019).
} 
to waive treatment requirements for patients if they feel it is medically unnecessary $^{27}$. Doctors have greater confidence within the legal framework.

The approaches of Japan and Korea share some common features. They both allow suffering patients to opt out of life support, but they are cautious about making surrogate decisions, especially from family members.

However, when patients' true wishes cannot be determined by their previous behavior, Korea requires the full agreement of all family members ${ }^{28}$.

Scientists say that the legal right to euthanasia will help establish his moral recognition, and that, as well as a deeper understanding of the conditions under which suicide can be rationally considered a potential choice. This is due to the fact that, of course, it is not expected that the members of the group who carry out abortion campaigns will retain all forms of euthanasia illegally. Greater public support for voluntary euthanasia does not seem to be reflected in physicians 'views, as studies of oncologists' views on euthanasia and physician-assisted suicide have shown. For example, in the case of an incurable patient (prostate cancer) with constant pain, only $22.5 \%$ of physicians supported physician-assisted suicide and only $6.5 \%$ of euthanasia. These results were significantly lower than in the previous study (since 1994, recent data were collected in 1998), in which $45.5 \%$ supported physician-assisted suicide and $22.7 \%$ supported euthanasia; life termination and palliative care were considered the best ways to handle terminal cases. Despite the opinion of doctors, $62.9 \%$ received requests for euthanasia or physician-assisted suicide from their patients ${ }^{29}$.

Scientist MS Wolf argues that, from a legal point of view, current laws that prohibit euthanasia are of great benefit in four main areas: 1) in the formulation of treatment that is given to patients without complying with the law (through non-regulation of euthanasia) and, therefore, also allowing informal processes who demonstrate trust in doctors; 2) allow the courts to decide to refuse life-support treatment; 3 ) compulsory patient care until the very end, and 4) due to the fact that the hospital bed is a safe place to discuss options ${ }^{30}$.

\footnotetext{
${ }^{27}$ Ethics in Medical Field. URL: http://kams.or.kr/webzine/14vol55/sub01.php (accessed: 21.05.2019.)

${ }^{28}$ Chih-hsiung Chen. Legislating the Right-To-Die With Dignity in a Confucian Society. Taiwan's Patient Right to Autonomy. Act 42 HastingsInt'l \& Comp. L. Rev. 2019. 485. URL: https://repository.uchastings.edu/hastings_international_comparative_law_review/vol42/iss2/4 (accessed: 26.09.2019).

${ }^{29}$ Andrew Oberg. Reconsidering euthanasia: For a right to be euthanized and for recognizing alternative end of life methods. Journal of International Philosophy. 2015. No. 4. P. 297.

${ }^{30}$ Susan M. Wolf. Holding the Line on Euthanasia. The Hastings Center Report. 19:1. 1989. P. 13-15.
} 


\section{Legal regulation of euthanasia in Taiwan}

In Taiwan, euthanasia has risen to the government level in 2010, when a woman, Wang Xiao-min, who died at the age of 64, had a car accident and was in a vegetative state for almost 50 years. Her parents repeatedly sought permission for euthanasia, but unfortunately, to no avail, they died sooner than she did. In 2000, the Law on Palliative Care in Hospice was adopted. This is why the Taiwan Patient Right to Autonomy Act (自主 權利 法), which was enacted by Legislative Yuan on December 18, 2015 and came into force in January 2019, has attracted much attention. The law was drafted by Professor Sun Hsiao-chih and Yang Yu-Xing, Honorary Advisor to the Taiwan Legislator ${ }^{31}$. This is Asia's first "natural death" law, which focuses on the good quality of death, promoting a concept that aims to pacify and provide medical assistance to patients to avoid stress and suffering for patients and their families, which has specifically protected the right patient for autonomy and set a precedent.

In Taiwan guarantee patient-centric is the patient's right to information, freedom of choice and decision in choice of behavior. She gave the patient the right to make decisions in the field of health care and a good death. The law stipulates that any person aged 20 years and above with full civil capacity has a priority right to information, choice and decision-making regarding the diagnosis and treatment options. In addition, with the help of pre-planning and preparatory assistance where the patient meets one of the five clinical conditions, he or she may accept treatment or to refuse it. In addition, the assigned medical agent can express an opinion, that the patient is in a coma or unable to clearly express own thought.

The five clinical conditions include: A. The patient is terminally ill. B. The patient is in an irreversible coma. C. The patient is in a constant vegetative state. $\mathrm{D}$. The patient has severe dementia. E. Other diseases declared by the Central Competent Authority that must meet all the following requirements so that the conditions or suffering are unbearable, that the disease is incurable and that there are no other appropriate treatment options based on medical standards at the time of the illness.

Most Taiwanese are not familiar with this law on patient health autonomy, and are easily confused with the law on palliative care for hospices. In order to make the public aware of the essence of the Patient's Right to Autonomy, the Ministry of Health and Social Welfare specifically commissioned 7 hospitals in Taiwan in early 2017 to test this law. Thus, medical staff or social workers have studied the provisions of the 2015 law for 3 years and can interpret it to interested people, patients and their

\footnotetext{
${ }^{31}$ Patient Autonomy Act. 2016. URL: http://www.dignitas.ch/images/stories/pdf/gesetztaiwan-patient-autonomy-act.pdf (accessed: 26.09.2019).
} 
families $^{32}$. It is the first law in Asia to grant terminally ill patients, including the elderly with severe dementia, the right to recognize the disease, to choose and to determine treatment options, providing the will to be fulfilled when the patient is comatose or unconscious. The patient may decide whether to continue medical treatment to prolong his life if he becomes terminally ill or unable to make decisions. The surrogate is administered if the patient is mentally or physically incapacitated ${ }^{33}$. The Natural Death Act was initiated in 2000, which allows a physician to refuse treatment for a terminal patient based on the patient's will to achieve a good death. The Natural Death Act was amended in 2013 to allow a physician to withdraw life-support treatment based on the patient's will to achieve a good death. Thus, the Natural Death Act, which was initiated in 2000 and amended in 2013, empowers medical teams to act for the benefit of terminally ill patients when no prior statement or surrogate exists ${ }^{34}$.

Prior to this, there was only the Hospice Palliative Care Act (term 寧 緩 和 醫療 條例), which is intended only for patients with a terminal illness: it allows a competent patient to relinquish vain support for life, even if he is terminally ill, or to family members for incompetent patients. It did not apply to people in a vegetative state (such as Wang Xiao-min), leaving 3684 Taiwanese families without the right to appeal from their position at the end of 2017. And even more Taiwanese who have fallen into a permanent coma or suffer from an extremely serious illness and are also left without rights. Yang Yusin, a lawmaker from 2012 to 2016 who has a rare disease, once visited family members of nearly 200 patients with rare diseases, and "each spoke of suicide," he remembers feeling frustrated. Some of the people he encountered went through 10 to 20 years of hardship, seeking relatives who had lost consciousness and were on artificial respirators to stay alive ${ }^{35}$. However, many polls have recently shown that $70-80 \%$ of people support euthanasia, considering that Taiwanese accept the idea of legalizing it ${ }^{36}$.

The Law on the Patient's Right to Autonomy goes beyond the terminally ill: irreversible coma; stable vegetative state; severe cognitive impairment, other officially declared irreversible conditions. According to Taiwanese lawmaker Yang Yusin, who headed the commission to pass the Patient's

${ }^{32}$ Chun-Ying Cho. From cure to care: the development of hospice care in Taiwan. Hospice \& Palliative Medicine International Journal. 2018. Vol. 2. Issue 5. P. 286-287. URL: https://medcraveonline.com/HPMIJ/HPMIJ-02-00108.pdf (accessed: 26.09.2019).

33 Shao-Yi Cheng. End of Life Questions Taiwan perspectives. URL: http://cmaao.org/news/pdf/symposium2017_32nd/8_Taiwan.pdf (accessed: 26.09.2019).

${ }^{34}$ Ibid. (Accessed: 01.06.2019).

${ }^{35}$ Sharon Tseng. Asia’s First 'Natural Death' Law, Will Taiwan be Ready? 2018. URL: https://english.cw.com.tw/article/article.action?id=1975 (accessed: 26.09.2019).

${ }^{36}$ Lu Alkohol. The Future of Euthanasia in Taiwan. URL: https://www.shs.edu.tw/works/ essay/2015/11/2015111421180943.pdf (accessed: 26.09.2019). 
Autonomy Law, noted that in connection with individual articles in the Medical Assistance Act, the Medical Act and the Taiwan Criminal Code, if a patient does not have legal documents signed under the Hospice Palliative Care Act or the Patient's Right to Autonomy Act, the physician must perform resuscitation for all patients ${ }^{37}$ (Table 1$)$.

Table 1

\begin{tabular}{|c|c|c|}
\hline «On palliative care of hospices» & $\begin{array}{c}\text { Comparative } \\
\text { Laws } \\
\text { of Taiwan } \\
\end{array}$ & $\begin{array}{l}\text { on the Patient's Right } \\
\text { to Autonomy }\end{array}$ \\
\hline $\begin{array}{l}\text { Terminally ill patients (cancer } \\
\text { patients in the last stage with the } \\
\text { possibility of living for no more } \\
\text { than } 6 \text { months) }\end{array}$ & $\begin{array}{l}\text { Objectives } \\
\text { of the laws }\end{array}$ & $\begin{array}{l}\text { 1. Terminally ill patients. } \\
\text { 2. Patients in irreversible } \\
\text { coma. } \\
\text { 3. Patients in a permanent } \\
\text { vegetative state. } \\
\text { 4. Patients with severe } \\
\text { dementia. } \\
\text { 5. Patients with other } \\
\text { serious diseases. }\end{array}$ \\
\hline 1. Artificial resuscitation. & $\begin{array}{l}\text { Treatment } \\
\text { that can be } \\
\text { denied }\end{array}$ & $\begin{array}{l}\text { 1. Lifelong treatment such } \\
\text { as resuscitation, } \\
\text { ventilation, blood } \\
\text { transfusion, chemotherapy, } \\
\text { dialysis, or antibiotics. }\end{array}$ \\
\hline $\begin{array}{l}\text { 2. Continuing treatment that } \\
\text { supports the patient's vital signs } \\
\text { and keeping them alive without any } \\
\text { chance of improvement. }\end{array}$ & Documents & $\begin{array}{l}\text { 2. Artificial nutrition and } \\
\text { hydration (nasogastric tube } \\
\text { for feeding). }\end{array}$ \\
\hline $\begin{array}{l}\text { Letter of Intent, signed personally } \\
\text { or by a family member in which the } \\
\text { decision is made in advance to } \\
\text { receive palliative care, stay in } \\
\text { hospice or receive treatment for life } \\
\text { extension. Documents Form of a } \\
\text { previous directive that can only be } \\
\text { signed by an interested person. }\end{array}$ & & $\begin{array}{l}\text { Form of a previous } \\
\text { directive that can only be } \\
\text { signed by an interested } \\
\text { person. }\end{array}$ \\
\hline $\begin{array}{l}\text { They will not be required before } \\
\text { signing the letter of intent }\end{array}$ & $\begin{array}{l}\text { Pre-signed } \\
\text { medical } \\
\text { consultations }\end{array}$ & $\begin{array}{l}\text { Must be legally involved } \\
\text { in "advance care planning" } \\
\text { before prior directives can } \\
\text { be signed. }\end{array}$ \\
\hline
\end{tabular}

${ }^{37}$ Tse Chun Yan. Ethical Challenges in End-of-Life Care: Local Perspectives in Hong Kong. URL: http://bioethics.med.cuhk.edu.hk/assets/files/userupload/Chun\%20Yan\% 20Tse_Ethical\%20Challenges\%20in\%20EOL\%20care\%20CU\%20Dec\%202017.pdf (accessed: 26.09.2019). 
The law is also part of standard palliative care to respect patients who wish to speed up their deaths (including euthanasia and assisted suicide care (hereinafter referred to as ADPs)). Health care professionals should recognize these wishes and requests and interpret them as a starting point for holistic care, with adequate symptom control to relieve suffering, psychologically adequate and spiritual care and intensive communication to better understand the underlying motives and attitude of the patient. Many patients may not have the information, have misconceptions about the progression of the disease, or fearful images of complications that are expected in the future as the disease progresses. For these patients, it is not their current state, but the expectation of suffering and fear that prompts the desire for a hasty death. It should be recognized and discussed with the patient, and offer and provide appropriate psychosocial and spiritual assistance.

The International Hospice and Palliative Care Association (IAHPD) believes that no country or state should consider legalizing euthanasia or ADP until it has universal access to palliative care and related medications, including opioids for pain and shortness of breath. In countries where euthanasia and / or ADPS are legal, the IAHP agrees that palliative care units should not be responsible for overseeing and administering these practices.

The law or policy should state that any health care provider who has a disagreement should be allowed to opt out ${ }^{38}$.

Taiwan's Law on Palliative Care for Hospices does not have strict requirements for surrogate decision-making. Some scholars have criticized this as a defect in the Law on Palliative Hospice Care. The Patient's Right to Autonomy Act corrects this shortcoming, but sets out clearer procedures to make patients' wishes effective and extend decision-making power to patients who are not terminally ill. This is an important milestone in East Asian law, as many Asian countries become aging societies, and the importance of end-of-life problems increases. The benefits and difficulties arising from the implementation of the Patient Right to Autonomy Law can be a great example of relevant reforms in East Asia. The Patient's Right to Autonomy Act protects patients' right to make previous decisions and their absolute autonomy in decisions, termination of life, and defines the procedures for making such decisions ${ }^{39}$.

${ }^{38}$ Liliana De Lima, Roger Woodruff, Katherine Pettus, Julia Downing, Rosa Buitrago, Esther Munyoro, Chitra Venkateswaran, Sushma Bhatnagar, Lukas Radbruch. International Association for Hospice and Palliative Care Position Statement: Euthanasia and Physician-Assisted Suicide. Journal of palliative medicine. 2017. Vol. 20. No 1. P. 10. URL: https://www.ncbi.nlm.nih.gov/ pmc/articles/PMC5177996/ (accessed: 26.09.2019).

${ }^{39}$ Chih-hsiung Chen, Legislating the Right-To-Die With Dignity in a Confucian Society. Taiwan's Patient Right to Autonomy Act, 42 HastingsInt'l \& Comp.L. Rev. 2019. 485. URL: https://repository.uchastings.edu/hastings_international_comparative_law_review/vol42/iss2/4 (accessed: 26.09.2019). 
This the regulation is a progression in Asian culture, where family relationships are highly valued. For example, the husband of Chinese writer Yao Chiung (Yao Chiung) is constantly ventilated. He can communicate with his children and doctors using simple language and therefore cannot be considered terminally ill. Fu Da-jen, a former television sports commentator in Taiwan, was in the final stages of pancreatic cancer before he died in Switzerland. However, he did not need emergency treatment to support life. In addition, the medical assistance he requested was not allowed in Taiwan. Neither Yao Jun's husband nor Da-eun Fu is covered by the Law on the Patient's Right to Autonomy or the Law on Palliative Hospice Care. As the Taiwanese public increasingly accepts the concept of "good death," Taiwan's next step may be to legalize physician-assisted suicide if the Patient's Right to Autonomy Act is enacted and implemented ${ }^{40}$.

\section{CONCLUSIONS}

So, the ability to perform voluntary euthanasia is aimed primarily at the well-being of patients, not the doctor, I think for the doctor it will be a burden. Family or friends may put pressure on patients to decide to end their lives, and while this cannot be completely ruled out, or family and friends may pressure patients who do not necessarily have the best interests in mind patient, but the final choice is always left to the patient. Voluntary euthanasia will be considered beneficial if there is "respect for individuals for their autonomous elections", provided that these elections do not harm others. A legalized and regulated system of voluntary euthanasia is unlikely to lead to a homicide. The peculiarity of euthanasia in Korea and Japan is that there is no direct legal regulation by law, but given the peculiarity of the country, court decisions are followed, as well as strong paternalism, which leads to the impossibility of using active euthanasia, but possible suicide by a doctor. It is interesting that the opinion of close relatives is necessarily taken into account, in my opinion it is the most positive in these countries, since terminal patients who have no chance of life, for example, in the case of brain death, can allow such existence with active body functions. person and up to 3 years, which will only burden the relatives. Such patients can live without an artificial respiration apparatus. In my opinion, it is difficult to introduce active euthanasia in Ukraine, but physician-assisted suicide is one better way to respect the right to die with dignity.

The analyzed countries support passive euthanasia without a clear definition. I believe that any person over the age of 18 who is fully capable has the right to make a written statement that if he or she will at one time

\footnotetext{
${ }^{40}$ Chih-hsiung Chen, Legislating the Right-To-Die With Dignity in a Confucian Society Taiwan's Patient Right to Autonomy Act, Hastings International and Comparative Law Review. No 42, p. 485, 2019. URL: https://repository.uchastings.edu/hastings_international_comparative_ law_review/vol42/iss2/4 (accessed: 01.06.2019).
} 
suffer from a terminal condition, as a result of which he or she will not be able to make a statement or decide on his or her treatment or termination medical treatment, or at all any medical treatment he may receive, treatment should be discontinued and palliative care should be provided. The individual also has the right to entrust any decision-making, or cancellation of such statement to the competent agent by written power of attorney, or to grant such right to his lawyer. This statement shall come into force and remain in force if the principal becomes terminally ill and as a consequence is unable to make or notify his decision to treat or terminate it.

\section{SUMMARY}

The study focuses on the legal analysis of euthanasia in the countries of East Asia - Japan, South Korea and Taiwan. The peculiarity of euthanasia in these countries is found to be that there is no legal regulation of euthanasia, and there are separate laws that allow refusal of treatment, provide palliative care to patients, etc. The main obstacle to the official introduction of active euthanasia in these countries is religion.

It should be noted that passive euthanasia is not explicitly stated to be passive. Patients have the right to refuse treatment or artificial life support. And since 2019, Taiwan's Patient Right to Autonomy law sets out clearer procedures to make patients' wishes effective for discontinuation of treatment, and extends decision-making powers to patients who are not terminally ill. Important in Taiwan is the identification of 5 clinical conditions in which treatment can be refused.

\section{REFERENCES}

1. Dictionary of the Ukrainian language: in 11 volumes. Volume 2. 1971. Page. 453. URL: http://sum.in.ua/s/evfemizm (accessed: September 26, 2019).

2. Roy W Perrett. Buddhism, euthanasia and the sanctity of life. Journal of Medical Ethics. 1996. № 22. P. 311-312. URL: http://buddhism.lib.ntu.edu.tw/ FULLTEXT/JR-ADM/perrett.htm (accessed: 26.09.2019).

3. Miki Hayashi, Toshinori Kitamura. Euthanasia trials in Japan: Implications for legal and medical practice. International Journal of Law and Psychiatry. № 25. 2002. P. 560. URL: https://www.sciencedirect.com/ journal/international-journal-of-law-and-psychiatry/vol/25/issue/6 (accessed: 26.09.2019 p.).

4. Chih-hsiung Chen. Legislating the Right-To-Die With Dignity in a Confucian Society. Taiwan's Patient Right to Autonomy. Act 42 HastingsInt'l \& Comp. L. Rev. 2019. 485. URL: https://repository.uchastings.edu/ hastings_international__comparative_law_review/vol42/iss2/4 (accessed: 26.09.2019 p.). 
5. Euthanasia. Basic knowledge of modern terminology. Jiyukisma. 2007. C. 951, 953. (安楽死". 現代用語の基礎知識. 自由国民社. 2007).

6. Kenzo Hamano. Should Euthanasia be Legalized in Japan? The Importance of the Attitude Towards Life. URL: https://www.eubios.info/ ABC4/abc4110.htm (accessed: 26.09.2019).

7. Kai K. (1995, March 28). Chiryoukouityuushi oyobi anrakushi no kyoyouyouken - Toukaidaigaku byouin "anrakushi"' - jiken hanketsu (Heisei 7.3.28, Yokohama Chisai hanketsu) (Permissible euthanasia - Tokai University "euthanasia" case (Judgement of Yokohama District Court)). Hougakukyoushitsu, 178. P. 37-45; Kai I., Ohi, G., Yano, E., Kobayashi, Y., Miyama, T., Niino, N., \& Naka, K. (1993). Communication between patients and physicians about terminal care: a survey in Japan. Social Science and Medicine. 1993. Vol. 36. P. 1151-1158.

8. McDougall Jennifer Fecio. Gorman Martha. Euthanasia: A Reference Handbook. Santa Barbara: ABC-CLIO. 2008. 270 p.

9. Tanya Thomas. Euthanasia Legal for the Terminally Ill In S. Korea Now. Med India. Retrieved 15 July 2010. URL: https://www.medindia.net/ news/euthanasia-legal-for-the-terminally-ill-in-skorea-now-71327-1.htm (accessed: 26.09.2019).

10. Alex Schadenberg. Korea has not legalized euthanasia or assisted suicide. Life site. Retrieved 14 December 2015. URL: https://www.lifesitenews.com/pulse/korean-has-not-legalized-euthanasia-orassisted-suicide (accessed: 26.09.2019).

11. South Korea Authorizes Country's First Mercy Killing. URL: https://www.fastcase.com/blog/south-korea-authorizes-coutrys-first-mercykilling/ (accessed: 26.09.2019).

12. Young Ho Yun, Kyoung-Nam Kim, in-Ah Sim, Shin Hye Yoo, Miso Kim, Young Ae Kim, Beo Deul Kang, Hyun-Jeong Shim, Eun-Kee Song, Jung Hun Kang, Jung Hye Kwon, Jung Lim Lee, Eun Mi Nam, Chi Hoon Maeng, Eun Joo Kang, Young Rok Do, Yoon Seok Choi, and Kyung Hae Jung. Attitudes of Cancer Patients, Family Caregivers, Physicians, and the General Population toward Modes of Death. Comparison of attitudes towards five end-of-life care interventions (active pain control, withdrawal of futile life-sustaining treatment, passive euthanasia, active euthanasia and physician-assisted suicide): a multicentred cross-sectional survey of Korean patients with cancer, their family caregivers, physicians and the general Korean population. URL: https://www.ncbi.nlm.nih.gov/pmc/articles/ PMC6144336/ (accessed: 26.09.2019).

13. Gupta B.D. Euthanasia: Personal Viewpoint. Jpafmat. 2004. № 4. P. 18. URL: http://medind.nic.in/jbc/t04/i1/jbct04i1p17.pdf (accessed: 26.09.2019 p.) 
14. New law enables South Koreans to 'die well". The Straits Times. 2016-01-28. Retrieved 29 January 2016. https://www.straitstimes.com/asia/ east-asia/new-law-enables-south-koreans-to-die-well (accessed: 26.09.2019).

15. Choi Won-woo. 조선일보. Korea to Temporarily Allow Terminally Ill Patients to Choose Death with Dignity. Retrieved 23 October 2017. URL: http://english.chosun.com/site/data/html_dir/2017/10/23/2017102301468. html (accessed: 26.09.2019).

16. Katsunori Kai. Euthanasia and Death with Dignity in Japanese Law. Waseda Bulletin of Compartive Law. 2010. Vol. 27. URL: https://www.waseda.jp/folaw/icl/assets/uploads/2014/05/A02859211-00000270001.pdf (accessed: 26.09.2019).

17. Ole Doering. Euthanasia, and the Meaning of Death and Dying: A Confucian Inspiration for Today's Medical Ethics. 2001. P. 56. URL: https://pdfs.semanticscholar.org/1f3f/a32d070818eb636a0be4f261eb69a24a 314a.pdf (accessed: 26.09.2019).

18. Ock-Joo Kim, Yoon Hyung Park, Byung Gee Hyun. Development of the codes and guidelines of medical ethics in Korea. J Korean Med Assoc. 2017. № 60(1). P. 8-17. URL: https://www.jkma.org/search.php?where= aview\&id $=10.5124 / \quad$ jkma.2017.60.1.8\&code=0119JKMA\&vmode $=$ FULL (accessed: 26.09.2019).

19. Ethics in the medical field.URL: http://kams.or.kr/webzine/ 14vol55/sub01.php (accessed: 21.05.2019 p.)

20. Andrew Oberg. Reconsidering euthanasia: For a right to be euthanized and for recognizing alternative end of life methods. Journal of International Philosophy. 2015. No. 4. P. 297.

21. Susan M. Wolf. Holding the Line on Euthanasia. The Hastings Center Report. 19:1. 1989. P. 13-15.

22. Patient Autonomy Act. 2016. URL: http://www.dignitas.ch/images/ stories/ pdf/gesetz-taiwan-patient-autonomy-act.pdf (accessed: 26.09.2019).

23. Chun-Ying Cho. From cure to care: the development of hospice care in Taiwan. Hospice \& Palliative Medicine International Journal. 2018. Vol. 2. Issue 5. P. 286-287. URL: https://medcraveonline.com/HPMIJ/ HPMIJ-02-00108.pdf (accessed: 26.09.2019).

24. Shao-Yi Cheng. End of Life Questions Taiwan perspectives. URL: http://cmaao.org/news/pdf/symposium2017_32nd/8_Taiwan.pdf (26.09.2019).

25. Sharon Tseng. Asia's First 'Natural Death' Law, Will Taiwan be Ready? 2018. URL: https://english.cw.com.tw/article/article.action?id=1975 (accessed: 26.09.2019).

26. Lu Alkohol. The Future of Euthanasia in Taiwan. URL: https://www.shs.edu.tw/works/essay/2015/11/2015111421180943.pdf.

27. Tse Chun Yan. Ethical Challenges in End-of-Life Care: Local Perspectives in Hong Kong. URL: http://bioethics.med.cuhk.edu.hk/ 36 
assets/files/userupload/Chun\%20Yan\%20Tse_Ethical\%20Challenges\% 20in\%20EOL\%20care\%20CU\%20Dec\%202017.pdf (accessed: 26.09.2019).

28. Liliana De Lima, Roger Woodruff, Katherine Pettus, Julia Downing, Rosa Buitrago, Esther Munyoro, Chitra Venkateswaran, Sushma Bhatnagar, Lukas Radbruch. International Association for Hospice and Palliative Care Position Statement: Euthanasia and Physician-Assisted Suicide. Journal of palliative medicine. 2017. Vol. 20. No 1. P. 10 P. 8-15. URL: https://www.ncbi.nlm.nih.gov/pmc/articles/PMC5177996/ (accessed: 26.09.2019).

\section{Information about the author:}

Buletsa S. B.,

Doctor of Law, Professor, Head of the Department of Civil Law and Process of the Law Faculty,

Uzhhorod National University

26, Kapitulna str., Uzhhorod, Ukraine 